\title{
МЕТОДИЧНІ АСПЕКТИ ПЦВИЩЕННЯ ЕФЕКТИВНОСТІ ВИКЛАДАННЯ ФІЗІОЛОГІї ЗА УМОВ КРЕДИТНО-МОДУЛЬНОї СИСТЕМИ
}

\author{
ДВНЗ “Івано-Франківський національниймедичний університет” \\ METHODOLOGICAL ASPECTS OF INCREASING THE \\ EFFECTIVENESS OF TEACHING OF PHYSIOLOGY IN CASE OF \\ CREDIT-MODULAR SYSTEM
}

О. І. Тучак

O. I. Tuchak

\author{
SHEI "Ivano-Frankivsk National Medical University"
}

\begin{abstract}
Методика викладання теоретичних дисциплін (у тому числі фізіології) повинна постійно перебувати в пошуках нових ефективних педагогічних моделей для сприяння ефективному засвоснню інформації студентом, формування системи знань та навичок, необхідних майбутньому лікарю у його професійній діяльності.

Methods of teaching of theoretical subjects (physiology also) should always be on the lookout for new and effective teaching models to promote the effective assimilation of information to students, the formation of knowledge and skills required of the future doctors.
\end{abstract}

Вступ. У процесі вивчення теоретичних основ фізіології важливими є методи і технології викладання, які підвищують ефективність засвоєння інформації студентами. Мета вивчення дисципліни передбачає сформувати систему знань та навичок, необхідних майбутньому лікарю у його професійній діяльності.

Основна частина. Реформування системи вищої освіти згідно з європейськими стандартами і приєднання до Болонської декларації змушують переглянути зміст, методи і засоби навчання. Однією з ключових позицій $є$ постійний зворотний зв'язок зі студентом протягом навчального процесу, який підвищує мотивацію та продуктивність вивчення матеріалу $[1,2,4]$. Викладання певного теоретичного матеріалу водночас включає в себе велику кількість різноманітних прийомів, зокрема спілкування з викладачем на практичних, лабораторних і лекційних заняттях, а також допомогу студентові при виконанні самостійної роботи. Проведення досліджень під час практичного заняття та обгрунтування одержаних результатів, використовуючи теоретичні знання, значно підвищує якість і обсяг засвоєння матеріалу. Ефективними $є$ i демонстраційні презентації лабораторних робіт, які дозволяють студентові спостерігати за ходом робо-

(C) O. I. Тучак ти, яку практично неможливо виконати без спеціальних умов [5]. Ознайомлення з новими методиками досліджень підвищує інтерес до вивчення теоретичного матеріалу теми і створює підгрунтя для аналітико-синтетичних співвідношень між взаємозалежними галузями науки і практики [3]. Студент повинен бути постійно мотивований прикладним застосуванням набутих знань, тому для кожної теми заняття необхідно використовувати реальні приклади із практичної медицини, пов'язані з вивченим теоретичним матеріалом.

Фундаментальні науки, в тому числі фізіологія, несуть велику кількість інформації, яку необхідно запам'ятати, що значною мірою ускладнює навчальний процес. Сприйняття і утримання такого значного об'єму матеріалу потребує більше часу, уваги і певною мірою виснажує працездатність студента. Під час аудиторного заняття при розгляді теоретичних запитань для підвищення активності студентів ефективним $€$ використання нестандартних методів опитування. Прикладом $€$ поділ присутніх на окремі групи, для кожної з яких підготовлене завдання, оцінка якого включає час і якість його вирішення. Відповіді обговорюються і доповнюються всіма бажаючими, що помітно мобілізує та заставляє спільно працювати на результат навіть переважно інертних студентів. 
Значно підвищує активність аудиторії пропозиція самостійно сформулювати запитання для присутніх і аналогічно оцінити відповідь. Така форма спілкування мотивує студентів до поглибленого вивчення теми заняття з метою підвищення рівня готовності до нестандартних запитань колег та адекватної оцінки їхньої відповіді.

Ведення протоколів на кожному занятті дисциплінує студентів та сприяє закріпленню основних базисних матеріалів теми. Зекономити аудиторний час можна при використанні спеціально підготовлених методичних рекомендацій, у яких внесено теми занять, контрольні запитання, хід виконання передбачених робіт та літературу, необхідну для самостійної підготовки. Під час заняття студент записує одержані результати та аналізує висновки. Системність ведення протоколів та дотримання вимог при оформленні отриманих результатів і висновків враховується при комплексному оцінюванні підготовки до заняття.

Підвищує мотивацію до безперервного навчання можливість перескласти незадовільну оцінку за поточне заняття, а також негативні результати підсумкового модульного контролю. Важливість такого

\section{Література}

1. Вища медична освіта України на сучасному етапі / В. В. Лазоришинець, М. В. Банчук, О. П. Волосовець [та ін.]// Проблеми сучасної медичної науки та освіти. - 2008. №4.- C. 5-10.

2. Досвід впровадження кредитно-модульної системи при викладанні фізіології / О. Г. Родинський, О.М.Демченко, О. В. Мозгунов [та ін.] // Медична освіта. - 2011. - № 3.C. $125-128$.

3. Інтеграція в Свропейський освітній простір як шлях покращення післядипломної підготовки лікарів / О.М.Хвисюк, В. Г. Марченко, І. А. Жадан [та ін.] // Медична освіта. -2010. -№3. - C. 77-78. підходу до можливості підняти свій рейтинговий бал за умов кредитно-модульної системи полягає, перш за все, у відповідальності перед вимогами майбутньої професії [6]. Акцентування на цінності кожної теми для подальшого розуміння складних механізмів взаєморегуляції фізіологічних процесів та усвідомлення суті функціонування цілісного людського організму сприяє досконалому опрацюванню тематичного матеріалу. Набуті в процесі вивчення предмета знання систематизуються в певний стереотип та інтегруються в освоєння нових розділів, а в подальшому і суміжних навчальних дисциплін на наступних курсах.

Висновок. Таким чином, навчання за кредитномодульною системою сприяє якісному та досконалому вивченню предмета. Аналіз та впровадження у педагогічну діяльність теоретично обгрунтованих сучасних положень, застосування нових методів i прийомів організації навчально-пізнавальної діяльності студентів формують мотиваційний, свідомий підхід до навчання та систематизують отримані знання для їх повноцінного використання в майбутній професійній діяльності.

4. Чекман I. С. Доказова медицина як методологічна основа формування нового світогляду майбутнього лікаря в системі кредитно-модульної освіти / I. С. Чекман, О. В. Шумейко, Н. В. Савченко // Медична освіта. -2010. № 3. - С. 84-86.

5. Шандра О. А. Впровадження альтернативних комп’ютерних технологій до навчального процесу на кафедрі нормальної фізіології ОДМУ - нові можливості / О. А. Шандра, О. А. Кащенко // Медична освіта. -2007.-№ 3.-С. 108-109.

6. Ярощук Л. Г. Основи педагогічних вимірювань та моніторингу якості освіти : навчальний посібник / Л. Г. Ярощук. - Луцьк, 2010.-308 с.

Отримано 14.04.14 